LENTERA PENDIDIKAN, EDISI X, NO. 1, JUNI 2007 (34-51)

\title{
MEMBANGUN MOTIVASI BERPRESTASI: Pengembangan Self Efficacy dan Penerapannya dalam Dunia Pendidikan
}

\author{
Oleh: Abdul Rahman Barakatu
}

\begin{abstract}
All individuals wish to get achievement in their activities done, including take formal education institution levels, but their wishes sometimes getting failure and cannot be achieved. There are a lot of students facing some difficulties and they are difficult to overcome them. One of the handicaps is psychological problem, because intrinsically he/she has failure imagination that cannot face the subject or finish his/her task. Bandura states that a construction psychology is called self efficacy. He believes that individual who has self efficacy grow up successful motivation.
\end{abstract}

KEYWORDS: Self efficacy, motivasi berprestasi, fundamental attribution error.

PERSATUAN Bulutangkis Seluruh Indonesia (PBSI) mengharapkan Bambang Supriyanto, seorang pemain bulutangkis Indonesia, mampu menjuarai kejuaraan bulutangkis internasional berbintang lima. Namun, pada awalnya, hal itu tidak dapat terwujud. Bambang gagal memenangkan pertandingan. Bahkan, terjadi hal yang sebaliknya, kekalahan yang dideritanya menjadi bumerang baginya. Dia mengalami kekalahan bila berhadapan dengan rivalnya di final atau di semi final setiap mengikuti pertandingan serupa.

Suatu saat tim pelatih Indonesia bersepakat hanya mengirim Bambang Supriyanto ke pertandingan bulutangkis yang lebih rendah tarafnya di Copenhagen. Dia berhasil menjadi juara. Pada pertandingan berikutnya pada level yang sama, dia selalu sukses memenangkan pertandingan dan menjadi yang terbaik. Pada saat itulah tumbuh kepercayaan dalam dirinya bahwa sebenarnya dia memiliki kemampuan untuk menjadi juara.

Pada waktu dia dikirim kembali untuk mengikuti pertandingan bulutangkis bintang lima, dia berhasil menjadi juara. Dia memenangkan kejuaraan-kejuaraan serupa dan mendapatkan berbagai penghargaan atas keberhasilannya. Bambang Supriyanto tercatat sebagai pribadi yang mampu mengangkat dirinya berprestasi dalam dunia bulutangkis. Dia menjadi 
juara yang melanglang buana dari satu even kejuaraan ke even kejuaraan bulutangkis yang lain. Dia mampu mengalahkan pemain utama tingkat dunia yang berasal dari negara manapun. Dia berhasil membabat habis semua lawan-lawannya untuk meraih prestasi tertinggi dan menjadi juara dunia bulutangkis internasional pada zamannya.

Fenomena Bambang Supriyanto dapat dianalisis dengan satu konstruk psikologis yang disebut dengan self efficacy. Self efficacy merupakan konstruk psikologi yang diajukan oleh Bandura, tokoh social learning theory. Self efficacy menjelaskan alur perkembangan kepribadian seorang individu menuju suatu kesuksesan. Individu yang memiliki self efficacy yang positif akan cenderung meraih kesuksesan dibandingkan dengan kegagalan. Bandura menyatakan bahwa self efficacy meningkatkan peluang seseorang untuk sukses, dan self efficacy akan mempengaruhi kemampuan seseorang untuk mengatasi tantangan atau hambatan untuk meraih keberhasilan.

Dalam artikel ini akan dikemukakan uraian mengenai self efficacy yang meliputi pengertian self efficacy dari sudut pandang social learning theory, proses pertumbuhannya, hubungannya dengan motivasi berprestasi, dan penerapannya dalam dunia pendidikan.

\section{PENGERTIAN SELF EFFICACY}

Self efficacy merupakan istilah yang dikembangkan oleh Bandura. Dia menyatakan bahwa ada dua proses belajar yang terpenting, yakni: (1) learning by observation, dan (2) vicarious learning. Pada proses belajar yang pertama, manusia belajar melalui pengamatan terhadap perilaku orang lain. Pada proses belajar yang kedua, manusia belajar mengamati konsekuensi perilaku orang lain. Kedua jenis proses belajar ini menampilkan model perilaku tertentu. Individu yang mengamatinya cenderung akan menirunya selama perilaku tersebut dapat memenuhi harapannya. ${ }^{1}$ Bila individu berhasil menguasai perilaku-perilaku yang ditirunya, dia akan merasa mampu melaksanakan perilaku berikutnya kalau dia ditugaskan untuk melakukannya kembali.

Dalam bulu tangkis, individu berlatih teknik mengarahkan bulu dengan berbagai teknik pukulan melalui pengamatan. Pengamatan itu ditempuh dengan berbagai cara apakah di lapangan secara langsung atau melalui video tape yang telah merekam sejumlah jenis pukulan. Pemain kemudian berlatih kembali dengan berupaya meniru teknik-teknik pukulan tersebut. Pemain-pemain yang berhasil menguasai dengan baik teknik bermain bulutangkis akan memilki rasa ampuh diri dalam menghadapi pertandingan yang akan diikutinya. Rasa ampuh diri ini disebut dengan self efficacy. 
Seorang indvidu perlu memiliki self efficacy dalam menjalankan satu kegiatan. Hal ini dimaksudkan untuk menumbuhkan kepercayaan dalam diri individu bahwa yang bersangkutan memiliki kemampuan untuk berhasil dengan sukses melakukan sesuatu dan mampu menghadapi berbagai tantangan kehidupan yang ada di dalam lingkungan sekitarnya. Bandura menyatakan bahwa "self efficacy is the confiction that one can successfully execute the behavior necessary to produce outcomes" 2 Stephen, Thomas, Joan \& John mengemukakan bahwa "self efficacy is individuals" beliefs in their ability to exert control over their lives; feeling of competency."3

Self efficacy merupakan istilah yang mempunyai aplikasi dalam berbagai bidang. Psikoterapi adalah salah satu bidang yang menggunakan konstruk self efficacy dalam membantu individu mengatasi berbagai gangguan emosional seperti ketakutan, kecemasan, pobia dan sebagainya. Dalam hal ini, psikoterapi mengaplikasikan self efficacy untuk menanamkan "the convidence that one can cope with the phobic situation."

Keyakinan akan keampuhan diri memberikan harapan bagi seorang klien mengatasi masalahnya. Pecandu narkoba umpamanya hanya dapat keluar dari jeratan obat-obat psikotropika bila dia memiliki self efficacy yang positif. Mereka memiliki keyakinan bahwa mereka mampu melakukan dan melalui serangkaian langkah-langkah treatment yang akan membawa dirinya dapat mengatasi ketergantungannya kepada penggunaan obat-obat terlarang.

Self efficacy berkaitan dengan persepsi individu ${ }^{5}$. Oleh karena itu, self efficacy dirumuskan sebagai "a person self perception of competence to enact a behavior or to handle a given type of situation."6 Self efficacy yang dinyatakan sebagai keyakinan bahwa orang dapat berhasil menjalankan tingkah laku yang diperlukan untuk membuahkan akibat tertentu. ${ }^{7}$ Keyakinan ini didasarkan pada interpretasi atau penilaian kognitif yang disebut dengan persepsi. Persepsi individu memandang dan menilai dirinya memiliki kemampuan untuk memecahkan masalah atau melaksanakan suatu kegiatan termasuk yang mengandung risiko dan berbahaya. Dalam hal ini, Smedlund menyatakan bahwa secara intrinsik self efficacy berhubungan dengan keterampilan memecahkan masalah. ${ }^{8}$

Persepsi tentang keampuhan dan kemampuan diri akan membangun self image dalam diri individu sehingga tumbuh pikiran positif setiap menghadapi suatu aktivitas atau masalah. Individu yang memiliki self effficacy akan lebih efisien memilih dan menata kegiatan yang akan dilakukannya agar dapat mencapai tujuannya. Dalam hal ini, Bandura menyimpulkan bahwa self efficacy berkaitan dengan tiga hal pokok, yakni:

1. perilaku memilih bukan sekedar satu motif dorongan (a drive motive). 
2. satu perilaku yang timbul dari satu informasi pengalaman langsung atau pengalaman mediasi.

3. satu "kemampuan memecahkan masalah" yang memperhitungkan situasi dan tugas; ia tidak dipandang sebagai satu sifat kepribadian yang bersifat global. ${ }^{9}$

Rasa kemampuan dan keampuhan diri memotivasi individu untuk berusaha mengubah dirinya secara positif menjadi individu-individu yang mampu berprestasi. Andrews menyatakan, "self efficacy is a central change mechanism or an epiphenomenon of other change."10 Seorang siswa yang memiliki self efficacy yang positif akan senantiasa berusaha mengubah hasil penampilan atau perilakunya, yang berupa hasil belajar, menjadi lebih baik. Dengan demikian, self efficacy dianggap menjadi dasar fundamental bagi individu untuk mengubah penampilannya ke arah yang lebih baik.

Individu yang tidak memiliki self efficacy cenderung memiliki pandangan yang negatif terhadap kemampuan dirinya. Individu tersebut biasanya merasa gagal sebelum melaksanakan sesuatu. Hal ini diperparah bila yang bersangkutan pernah mengalami kegagalan yang berakibat dia menderita gangguan traumatis dalam kehidupan kejiwaannya. Individu tersebut memiliki negative self attribution.

\section{PERTUMBUHAN SELF EFFICACY}

Self efficacy tidak muncul begitu saja. Ia tumbuh melalui suatu proses. Sebagai suatu konstruk yang berasal dari social learning theory, maka proses pertumbuhan self efficacy tidak terlepas dari kerangka teori observational learning dan vicarious learning yang memandang belajar merupakan proses interaksi berbagai variabel. Elliot et al. menyatakan bahwa variabel-variabel yang membentuk self efficacy tidak terlepas dari interaksi variabel tingkah laku, lingkungan, proses kognitif, dan faktor pribadi. ${ }^{11}$ Keempat variabel ini saling bertaut dan saling mempengaruhi satu dengan lainnya dalam membentuk self efficacy dalam diri individu.

Tingkah laku merupakan kegiatan yang dilaksanakan oleh individu model dalam satu kegiatan. Peranan pokok tingkah laku yang dijadikan model ialah menyampaikan informasi kepada si pengamat. Teori belajar sosial berpandangan bahwa hal yang amat penting ialah kemampuan individu mengambil sari informasi dari tingkah laku orang lain, memutuskan tingkah laku mana yang akan diambil, dan kemudian kesediaan untuk melaksanakan tingkah laku tersebut. ${ }^{12}$ Satu kali individu melakukan kegiatan tingkah laku dan merasa sukses mencapai suatu tujuan, maka self efficacy akan tumbuh dalam diri yang bersangkutan. 
Kemampuan untuk memilih tingkah laku efektif menjadi faktor yang sangat penting bagi pertumbuhan self efficacy. Tingkah laku yang kurang efektif menjadikan individu kurang percaya diri akan keberhasilannya dan akan menjadikannya frustrasi karena tingkah lakunya menjadi sia-sia dan tidak menghasilkan sesuatu yang bermanfaat baginya. Tingkah laku efektif yang dipilih dan dilaksanakan secara bertahap serta mendapatkan reinfors berupa reward akan semakin memperkuat keyakinan individu bahwa dia memiliki kemampuan melaksanakan sesuatu dengan baik dalam merespon dan menguasai lingkungannya. Social learning theory mengakui perspektif pilihan individu terhadap apa yang disediakan oleh lingkungan, tetapi individu juga memiliki rasa percaya diri untuk berbuat menguasai dan memodifikasi lingkungan.

Individu belajar melalui lingkungan. Lingkungan merupakan faktor eksternal yakni segenap faktor yang berada di luar diri manusia yang bisa berubah menjadi stimulus dan reinfors. Social learning theory berpandangan bahwa lingkungan memberikan berbagai model tingkah laku yang dapat ditiru. Sebagai contoh, dalam zikir bersama, individu dapat larut meniru model tingkah laku yang disediakan oleh lingkungan sekitarnya. Individu terkadang menangis sambil melantunkan bacaan zikir yang mengalun lembut seperti yang dilakukan individu lainnya atau orang yang ditokohkan. Mereka larut dalam berzikir karena berharap mendapatkan ketenangan batin sebagai reinfors yang berfungsi memperkuat perilaku berzikir.

Significant others merupakan pribadi-pribadi yang sangat besar kontribusinya dalam membentuk tingkah laku individu. Orang tua, guru, pejabat, pelatih, ulama, teman yang menjadi pemimpin merupakan significant others yang menjadi panutan orang sekitarnya selama perilakunya memberikan harapan bagi individu lainnya. Mereka menjadi model yang dapat menumbuhkan self efficacy dalam diri individu yang senang menirunya. Hal ini dapat terjadi karena proses hubungan yang diperkuat dengan otoritas significant others, kedekatan fisik, dan hubungan sosial yang erat. Model perilaku sukses yang ditampilkan oleh lingkungan dan significant others terserap ke dalam jaringan memori yang membentuk jaringan kognitif.

Proses kognitif merupakan kegiatan mental yang memediasi individu dengan lingkungan. Proses kognitif mengantar individu mengenal, menyerap, menyimpan bahkan mengolah dan memodifikasi berbagai model tingkah laku yang diamatinya dari lingkungan. Proses kognitif membuat dan menyusun kode tingkah laku yang ditiru dalam bentuk representasi simbolik yang kemudian tersimpan dalam memori. Gagne mengemukakan bahwa individu memiliki berbagai strategi kognitif, 
keterampilan intelektual, dan informasi verbal untuk memproses informasi yang masuk ke dalam memori kemudian individu mereproduksikannya kembali dalam bentuk tingkah laku motorik ataupun verbal yang diaplikasikan dalam menghadapi dan mengontrol lingkungan sekitar. ${ }^{13}$

Para terapis kognitif berkeyakinan bahwa positive believe sangat berpengaruh terhadap keberadaan self efficacy. Seorang yang memiliki negative believe terhadap kemampuannya untuk menghadapi sesuatu secara berhasil lebih banyak mengalami kegagalan. Kegagalan itupun akan semakin menambah perasaan tidak mampu untuk keluar dari jeratan masalah yang dihadapinya. Oleh karena itu, terapi yang ampuh adalah memproses perubahan cognitive believe dengan tindakan "correcting such cognitive distortions and misattribution... by cognitive reframing; ${ }^{14}$ atau dengan perlakuan "reconfirm self perception of inefficacy by disputing." 15

Pertumbuhan self efficacy juga bergantung kepada faktor pribadi. Faktor yang berpengaruh terhadap pribadi pada saat menjalankan suatu tugas berkaitan dengan tiga unsur pokok, yakni:

1. Structure Permanent Characteristic. Yaitu seluruh kecakapan dan karakteristik individu yang telah menetap dalam kepribadiannya yang merupakan hasil interaksi antara hereditas dan lingkungan. Termasuk ke dalam unsur ini adalah pendidikan, pengalaman, struktur masyarakat, jenis kelamin, falsafah hidup, pembawaan.

2. Temporary state. Keadaan dalam diri individu yang bersifat sementara, seperti sakit, marah, sedih, gembira, lapar dan sebagainya merupakan keadaan yang dapat mempengaruhi self efficacy. Orang yang sakit biasanya mempunyai pengaruh yang sangat besar terhadap penampilannya. Mereka akan merasa ragu terhadap kemampuannya untuk berhasil karena terganggu oleh keadaan sakit yang dideritanya. Sebaliknya orang sehat kemungkinannya akan berbuat lebih baik dalam menjalankan satu kegiatan tertentu.

3. Activity in process. Kegiatan yang sedang berlangsung. Orang yang sedang terlibat dalam satu kegiatan akan terbagi konsentrasi pemikirannya bila dihadapkan dengan kegiatan lain dalam waktu yang bersamaan. Pada saat dia memusatkan perhatiannya untuk menyelesaikan satu tugas, maka tugas yang lainnya akan terabaikan, paling tidak hasilnya tidak akan maksimal. ${ }^{16}$

Sehubungan dengan pertumbuhan self efficacy, Elliot, et. al., Barbara, dan Leslie mengemukakan bahwa self efficacy berasal dari informasi yang disampaikan oleh empat sumber, yakni:

1. Enactive mastery experiences.

2. Vicarious experiences. 
3. Verbal persuation.

4. Physiological and affective states. ${ }^{17}$

Secara umum, Enactive Mastery Experiences menunjukkan pengalaman individu memperolah kesuksesan mendapatkan keunggulan. Pengalaman ini bukan hanya mempengaruhi persepsi self efficacy sekarang, ia juga cenderung menggeneralisasi situasi lain. Individu memperoleh informasi efektif dari apa yang mereka kerjakan. Individu belajar dari pengalaman pertama bagaimana mereka sukses menguasai lingkungan. Goldfried \& Robin (1982); Wilson (1984); mengungkapkan “By attributing success experiences to themselves, these client can learn to enhance their self efficacy expectation and positive motivation." 18

Vicarious experiences juga berguna untuk meningkatkan self efficacy, walaupun tidak sesukses penampilan langsung dari model. Vicarious experiences termasuk berbagai bentuk modeling. Pembelajar meniru model yang mempunyai kelebihan menonjol. Pembelajar melihat model mendapatkan reinfors berupa insentif sehingga mendorong individu meniru perilaku kesuksesan model menjalankan tugas atau kegiatan. Dengan mengamati penampilan orang lain, individu memotivasi dirinya untuk mengerjakan kegiatan yang serupa.

Verbal persuation. Bujukan dapat menuntun seseorang untuk merasa yakin bahwa mereka dapat mengatasi kesulitan-kesulitan dan memperbaiki penampilan mereka. Kata-kata seperti "Anda mampu", "Anda kompeten", merupakan pemicu kepribadian untuk menuju kesuksesan. Walaupun demikian, bujukan mempunyai keterbatasan-keterbatasan karena individu tidak selalu siap untuk dibujuk apalagi bila yang bersangkutan mempunyai sejarah kegagalan. Akan tetapi, diyakini bahwa verbal persuation dapat mempunyai beberapa pengaruh, khususnya kalau diulangi sepanjang waktu dan dipasangkan dengan keunggulan penampilan.

Physiological and affective states. Situasi yang menegangkan merupakan satu sumber informasi personal. Jika kita memproyeksikan satu gambaran mengenai diri kita sebagai tidak layak dan merasa takut pada situasi tertentu, kemudian kita meningkatkan kemungkinan perilaku tersebut, maka peningkatan emosi itu dapat berperan menurunkan keampuhan diri. Ketakutan, kecemasan yang tinggi, dan kondisi menegangkan yang lain dapat melemahkan atau mengurangi penampilan seseorang. Sebaliknya, suasana psikologis yang kuat mendorong individu untuk melaksanakan suatu kegiatan dengan penuh kesungguhan. Individu akan memberikan partisipasi aktif dan positif ke arah usaha penyelesaian tugastugas dengan melakukan kegiatan yang mengantar kepada kesuksesan. 


\section{Motivasi Berprestasi}

Kesuksesan penampilan seorang individu selalu dikaitkan dengan motivasi. Motivasi merupakan salah satu aspek psikologis yang mendorong individu untuk memilih, melaksanakan, dan mengarahkan aktivitasnya. Semakin kuat motivasi seseorang semakin besar kemungkinannya dia berhasil melaksanakan satu kegiatan atau tugas. Slavin mendefinisikan motivasi sebagai "process internal that activates, guides, and maintains behaviors over time." 19

McClelland merupakan salah seorang psikolog yang membahas masalah motivasi. Dia menyatakan bahwa tingkah laku dipengaruhi oleh kebutuhan-kebutuhan yang ada dalam diri manusia. Salah satu kebutuhan manusia adalah need for achievement, yaitu kebutuhan untuk mencapai kesuksesan yang diukur berdasarkan standar kesempurnaan dalam diri seseorang. Kebutuhan ini mengarahkan tingkah laku pada usaha untuk mencapai prestasi tertentu. ${ }^{20}$

Self efficacy merupakan unsur pokok dalam menunjang kebutuhan

mencapai kesuksesan. Tanpa self efficacy yang positif manusia cenderung mengalami kegagalan apalagi bila tugas itu merupakan tantangan yang besar atau mempunyai risiko yang berat. Bandura (1977) dan kawankawan menunjukkan bahwa ekspektasi self efficacy yang rendah merupakan aspek sentral kegagalan untuk mengatasi secara efektif situasi yang membahayakan. Biasanya kegagalan dihubungkan dengan fundamental attribution error; individu melihat perilakunya sendiri sebagai ditentukan secara situasional, sebaliknya pengamat eksternal selalu membuat atribusi disposisional yang menganggap individu akan mengalami kegagalan. ${ }^{21}$ Fundamental attribution error biasanya sudah melekat dalam diri seseorang sebelum melaksanakan kegiatan, sehingga dia sudah gagal sebelum beraktivitas.

Johnson \& Johnson (1991) menyatakan bahwa motivasi pada umumnya dipandang sebagai kombinasi kemungkinan sukses yang diperoleh dan kemungkinan insentif yang didapatkan. ${ }^{22}$ Ekspektasi individu memperoleh kesuksesan merupakan faktor internal, sedangkan kemungkinan mendapatkan insentif merupakan faktor eksternal. Kedua faktor ini saling menunjang membangun motivasi dalam diri individu untuk berbuat.

Linda L. Davidoff (1991) melukiskan satu model cara kerja motivasi. Model ini menggambarkan pertautan antara faktor internal dan faktor eksternal yang mempengaruhi kognisi dan emosi individu, sehingga muncul motivasi untuk melakukan suatu perilaku. Model ini tercantum pada Gambar 1. 


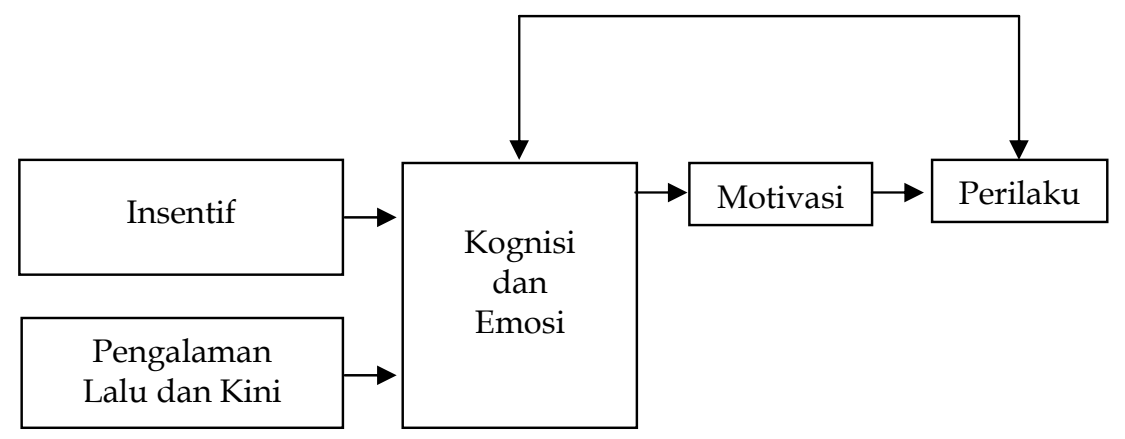

Gambar 1. Cara Kerja Motif23

Ekspektasi individu memperoleh kesuksesan tumbuh dari pengalaman masa lalu dan kini. Pengalaman memberikan keyakinan kepada dirinya bahwa dia memiliki kompetensi sehingga akan mampu berprestasi dalam melaksanakan satu kegiatan. Pengalaman merangsang kognisi dan emosi individu sehingga memiliki motivasi untuk berbuat. Dengan begitu, self efficacy merupakan faktor penentu proses kemunculan motivasi yang mendorong seorang individu melakukan satu perilaku. Tanpa self efficacy yang positif, individu akan merasa ragu atau bahkan tidak termotivasi untuk melakukan suatu kegiatan.

Faktor lain yang ikut berpengaruh terhadap motivasi adalah insentif. Pikiran dan perasaan akan mengidentifikasi satu aktivitas yang dapat memperoleh insentif. Kemampuan daya selektivitas terhadap perilaku yang memiliki kemungkinan mendapatkan insentif akan lebih cenderung diadopsi oleh individu. Keinginan untuk mendapatkan insentif merupakan sumber motivasi yang menggerakkan individu untuk memiliki dan melakukan suatu aktivitas tertentu. Pemberian insentif itu dapat diperkirakan berdasarkan pengamatan langsung maupun melalui belajar vicarious seperti yang dijelaskan terdahulu. Insentif berfungsi sebagai konsekuensi yang diterima sebagai hasil respon meniru satu perilaku dan sekaligus memperkuat perilaku itu untuk diulangi pada kesempatan yang lain. Seorang siswa yang mendapatkan pujian dari seorang guru, karena dia berhasil mengerjakan soal matematika sesuai dengan yang dicontohkan oleh gurunya, akan lebih termotivasi untuk menyenangi pelajaran matematika. Demikian pula seorang anak yang memperoleh hadiah dalam perlombaan english debate akan lebih termotivasi untuk meniru berbagai cara berdebat dalam bahasa Inggris. Hal ini memotivasi diri si pelaku sekaligus memberikan self efficacy positif yang lebih besar. Goldfried and Robin (1982) mengemukakan bahwa "... By attributing success experiences to 
themselves, these client can learn to enhance their self efficacy expectation and positive motivation. ${ }^{24}$ Kognisi dan emosi yang mempertimbangkan dan merasakan kesuksesan senantiasa selektif dan mendorong seseorang untuk senantiasa berbuat dan melaksanakan tugas-tugasnya dengan baik.

\section{Pertumbuhan Self Efficacy dalam Proses Belajar}

Self efficacy dan motivasi berprestasi dapat tumbuh berkembang dan sekaligus mempengaruhi proses belajar. Self efficacy dan motivasi berprestasi melandasi perbuatan belajar. Namun, self efficacy dan motivasi berprestasi juga tumbuh dari keberhasilan dalam belajar. Self efficacy dan motivasi berprestasi akan semakin tinggi dan kuat bila hasil belajar terdahulu mendapatkan hasil atau insentif yang berharga. Ini merupakan harapan setiap siswa. Harapan berhasil dan sukses disebut dengan efficacy expectation, yaitu menentukan berapa banyak usaha orang yang akan digunakan dan berapa lama mereka akan terus menerus mengusahakannya dalam menghadapi hambatan-hambatan dan pengalaman aversive. Tambah kuat self efficacy yang dirasakan, tambah aktif usaha-usaha yang dilakukan.

Belajar perilaku melalui learning observation atau vicarious learning ditempuh melalui empat proses. Proses-proses tersebut menumbuhkan sekaligus melibatkan self efficacy dan motivasi berprestasi yang mengantar siswa memperoleh hasil yang maksimal. Keempat proses tersebut adalah:

\section{Attention}

Tahap pertama belajar observasi adalah pemusatan perhatian kepada model. Tingkah laku belajar tidak akan diperoleh kecuali jika tingkah laku itu diperhatikan dan dipersepsi dengan cermat. Ada tiga faktor penting yang mempengaruhi perhatian, yakni: 1) ciri-ciri model, 2) nilai fungsional tingkah laku, dan 3) ciri-ciri si pengamat (siswa). ${ }^{25}$

Dalam pembelajaran, pengenalan terhadap ciri-ciri model perilaku sangat penting. Ciri-ciri model yang menarik perhatian akan membangkitkan motivasi siswa untuk menirunya. Pada umumnya siswa memusatkan perhatiannya kepada model yang memenuhi ciri mempunyai daya tarik, sukses, diminati dan terkenal. Itulah sebabnya banyak siswa yang tertarik kepada pakaian, bentuk rambut, dan gaya bintang budaya pop. Di dalam kelas, guru dapat menarik perhatian siswa dengan menyajikan isyarat-isyarat yang jelas dan menarik dengan menggunakan hal-hal baru dan mengesankan, sehingga siswa termotivasi untuk mengarahkan perhatiannya. Suara, mimik, ketulusan, kedisiplinan, tata cara mengajar, langkah-langkah strategi belajar mengajar yang ditunjukkan oleh seorang guru dapat menjadi sumber perhatian mahasiswa calon guru. 
Tulisan kaligrafi yang bervariasi dan berwarna dapat menarik perhatian siswa sehinga mereka termotivasi untuk menirunya. Langkahlangkah dan tingkah laku guru dalam mengajarkan dan melukiskan hurufhuruf kaligrafi itu cenderung untuk ditiru oleh siswa yang mempunyai minat mengembangkan diri dalam kaligrafi. Satu kali siswa berhasil dan mendapatkan reinfors, akan memberikan pengaruh terhadap pertumbuhan self efficacy dalam dirinya dan sekaligus memotivasinya untuk berbuat serupa.

Suara guru yang mengatakan, "dengarkan dengan baik, ini akan menjadi bahan ujian besok," menjadi sumber perhatian siswa. Nilai fungsional yang yang terdapat dalam perkataan guru, menjadi pemicu perhatian siswa sehingga mereka tertarik melihat perilaku guru memecahkan soal-soal matematika yang diperkirakan muncul dalam ujian. Menurut paham belajar sosial, orang mempunyai perhatian terhadap kejadian yang mengandung prediksi penguatan. Orang cenderung mengabaikan kejadian yang tidak mengandung ramalan penguatan. Isu gratis pendidikan dan kesehatan menjadi menarik dalam kampanye karena mengandung ramalan penguatan. Dalam pembelajaran guru dapat merancang kegiatan-kegiatan yang mengandung ramalan penguatan seperti kemungkinan bahan ajar akan menjadi bahan ujian.

Ciri-ciri si pengamat yang berpengaruh pada proses atensi ialah set perseptual, keterampilan observasi, tingkat tergeraknya diri (arousal), pengalaman sebelumnya, dan kapasitas sensori. Set perseptual dan tergeraknya diri mempengaruhi pemilihan aktivitas yang akan diobservasi, sedangkan keterampilan observasi berpengaruh pada kecermatan pemrosesan. ${ }^{26}$

Set perseptual adalah kesiapan persepsi untuk menangkap tingkah laku model yang diamati. Penggunaan berbagai jenis indera akan memperbaiki kualitas persepsi individu sehingga dapat menyerapnya ke dalam memori. Contoh-contoh yang jelas, suara yang bervariasi, grafik yang menarik akan membantu daya persepsi siswa.

\section{Retention}

Siswa akan mampu menyimpan model perilaku dalam memorinya bila dia mengarahkan perhatian kepada model tersebut. Tingkah laku model yang diterima oleh indera dikode dalam bentuk representasi simbolik, baik verbal maupun non verbal, kemudian disimpan dalam memori. Bagan yang jelas dan struktur materi yang menarik serta sistematis akan lebih mudah dicerna dan disimpan dalam memori jangka panjang. 
Latihan dan pengulangan akan memperkuat retensi. Kesempatan yang diberikan kepada siswa untuk berlatih membuat kaligrafi dengan contoh model yang menarik akan mempermudah siswa menyerap dan membuat kode representasi simbolik dalam memori. Qari dan qariah mampu melantunkan berbagai jenis lagu dalam Musabaqah Tilawatil Qur'an karena mereka sudah berlatih dan mengulangi model lagu yang diperagakan pelatihnya. Dalam hal ini, Thorndike mengemukakan law of exercise sebagai hukum yang berlaku dalam proses pembelajaran. Hukum ini menyatakan bahwa semakin sering suatu tingkah laku dipraktekkan dan diulangi, maka koneksi-koneksi antara model dan respon tingkah laku akan semakin kuat. ${ }^{27}$ Dengan begitu, model tingkah laku akan semakin tersimpan kuat dan bertahan lama bila sering diulang dan dipraktekkan.

Kemampuan meretensi suatu model perilaku menumbuhkan self efficacy. Representasi simbolik yang terdapat dalam memori memberikan keyakinan kepada individu bahwa dia mampu melakukan suatu tugas atau tingkah laku yang diharapkan. Hal ini disebabkan karena individu memperoleh bayangan tentang cara mereka bertindak untuk melaksanakan tugas. Mereka memahami langkah-langkah dan prosedur yang harus ditempuh dalam menjalankan suatu kegiatan. Self efficacy ini pula yang membangun motivasi berprestasi.

\section{Performance}

Tahap ini juga disebut tahap reproduksi. Selama tahap reproduksi, siswa berusaha mencocokkan perilaku mereka dengan model. Representasi simbolik menuntun individu untuk melakukan sesuatu yang pernah dialaminya. Siswa menampilkan kemampuan penguasaannya berdasarkan bayangan mental yang tersimpan dalam memorinya. Contoh qari dan qariah yang dikemukakan terdahulu menampilkan keterampilannya membaca al-Qur'an disesuaikan dengan model jenis lagu yang telah dipelajarinya. Di samping penampilan, sama dengan pelaku yang lain, qari dan qariah biasa berbicara dengan dirinya sendiri menilai bacaannya sendiri apakah sudah memenuhi standar atau belum. Siswa menilai penampilannya sendiri merupakan sistem penilaian yang dikembangkan pada abad 21 dengan porsi $50 \%$ dari keseluruhan proses penilaian. ${ }^{28}$ Penilaian terhadap kinerja berdasarkan penampilan merupakan penilaian yang sifatnya autentik.29

Pengukuran terhadap penampilan siswa dapat dilakukan di dalam kelas. Perilaku siswa disesuaikan dengan model yang telah ditampilkan. Cara siswa melakukan tata cara berwudhu' dibandingkan dengan sejumlah kriteria indikator model. Setiap penampilan yang sesuai dengan indikator 
model diberi insentif yang berfungsi memperkuat perilaku tersebut, sedangkan perilaku yang kurang sesuai dengan model diberikan tindakan remedial. Dengan demikian, dalam proses penampilan, guru berkewajiban memberikan feedback baik yang bersifat reinfors maupun yang bersifat perbaikan, sehingga dengan demikian perilaku siswa memperoleh standar yang diinginkan. Pemberian insentif dan feedback perbaikan menumbuhkan motivasi untuk melakukan sesuatu tingkah laku sesuai dengan standar.

Faktor kunci untuk meningkatkan self efficacy terletak pada penampilan yang sukses dalam melaksanakan tugas sesuai standar. Kesuksesan akan mempunyai peluang yang lebih besar mempengaruhi keyakinan individu untuk mampu berbuat. Mereka berkeyakinan memiliki kompetensi dan kapabilitas melaksanakan dan menyelesaikan setiap tugas dengan baik, karena mereka mempunyai pengalaman sukses sebelumnya.

Guru sebaiknya merancang suatu kondisi dan program pembelajaran yang lebih mudah bagi siswa yang mengalami kegagalan. Namun, harus disadari bahwa dalam sistem pembelajaran klasikal, hal ini tidak mudah untuk dilaksanakan. Hampir semua rancangan pembelajaran yang dipersiapkan dilandasi anggapan bahwa semua siswa mempunyai kemampuan yang sama. Padahal dalam realitas dan pandangan para psikolog menyatakan bahwa manusia mempunyai perbedaan individual. Penerapan mastery learning memungkinkan memperlakukan siswa secara berbeda menurut kecepatannya dalam menyerap pelajaran. Setiap individu siswa bisa maju berpacu menurut kecepatannya menguasai satu bidang.

Mastery learning mengharuskan guru merancang pembelajaran secara bertahap dan bertingkat dari bahan yang mudah ke bahan yang sulit untuk diserap. Bahan yang sulit hanya dapat dikuasai bilamana siswa sudah mampu menyerap bahan yang mudah. Bahan pelajaran pertama merupakan landasan bagi penguasaan bahan pelajaran berikutnya. ${ }^{30}$ Kemampuan berbahasa Inggris dan mata pelajaran lainnya terasa sangat sulit di kalangan siswa SMA disebabkan karena mereka kurang menguasai bahan ajar sebelumnya. Sebenarnya, bahan ajar terdahulu merupakan prasyarat untuk menguasai bahan ajar berikutnya.

Learning observation menunjukkan model perilaku. Dengan model ini diharapkan siswa mampu mendemonstrasikan perilaku sesuai model. ${ }^{31}$ Siswa yang belajar matematika memperoleh model penyelesaian soal, pelatihan, dan praktek dari guru. Langkah-langkah ini akan ditiru oleh siswa. Setelah itu, guru memberikan tantangan dengan penyajian soal yang dapat diselesaikan sesuai dengan langkah-langkah yang sudah ditampilkan. Kleiner, Marshall, and Spevack mengemukakan bahwa individu yang mendapatkan pemberian latihan dalam keterampilan mengidentifikasi dan 
mengatasi masalah terus menerus memperoleh perbaikan setelah follow up. ${ }^{32}$ Artinya, latihan, praktek, feedback, dan insentif akan terus meningkatkan dan memperkuat self efficacy.

\section{Motivasi}

Tahap akhir belajar observasi adalah motivasi. Motivasi mendorong dan menggiatkan siswa untuk meniru dan mencontoh perilaku model. Salah satu alasan siswa tergerak untuk meniru model karena mereka merasa bahwa dengan berbuat demikian akan meningkatkan peluang untuk mendapatkan insentif atau reinfors. Sebagai contoh, mereka meniru perilaku bintang pop karena dia akan menjadi populer di kalangan temantemannya. Dukungan teman untuk meniru suatu perilaku mempunyai pengaruh yang besar untuk memelihara peniruan tersebut. Bagaimanapun populer satu bintang rok, kalau teman sejawatnya tidak memberikan dukungan, maka siswa tidak akan mau menirunya.

Di dalam kelas, tahap motivasi ini lebih sering didorong dengan pemberian pujian dan nilai positif. Insentif yang diberikan kepada siswa yang mengarahkan perhatian kepada model, mempraktekkannya, dan mereproduksikan kembali kecakapannya karena mereka sudah mempelajarinya sesuai apa yang diinginkan dan disenangi guru sehinga mereka mendapatkan reinfors akan memperkuat keinginan siswa untuk belajar. Dorongan, sambutan hangat, penghargaan, dan pengakuan akan menumbuhkan self efficacy dan motivasi internal yang sangat bermanfaat dalam kegiatan belajar berikutnya.

Penggunaan secara efektif prinsip-prinsip Bandura mengenai belajar model dapat meningkatkan prestasi. Zimmerman \& Kleefeld (1977) mengemukakan fakta-fakta hasil penelitian yang menunjukkan bahwa guru-guru yang mengajarkan prinsip-prinsip belajar sosial (memelihara perhatian, melukiskan tiap perilaku sementara melakukannya, mengajarkan bantuanbantuan ingatan, dan membantu siswa mengevaluasi penampilannya sendiri) jauh lebih berhasil dalam mengajarkan konsep kepada anak-anak umur lima tahun daripada guru-guru yang tidak mengajarkan prinsip ini. ${ }^{33}$

Peningkatan self efficacy yang dirasakan oleh seseorang, kemungkinan untuk sukses pada satu tugas dan potensi memlihara usaha ke arah satu tugas juga meningkat. Karena itu self efficacy dapat menuntun ke arah penampilan yang lebih tinggi, yang pada gilirannya dapat membawa perasaan positif kepada diri.

Goldfried and Robin sudah membahas cara-cara meningkatkan persepsi self efficacy yang digeneralisasi yang dapat digabungkan ke dalam self-concept global client. Metode ini membantu client melawan perilaku 
mereka yang dahulu sampai sekarang dan membantu menumbuhkan atribusi internal untuk berubah.

\section{PENUTUP}

Self efficacy adalah keyakinan individu yang memiliki persepsi bahwa dia memiliki kemampuan dan kompetensi untuk sukses melaksanakan suatu tugas atau pekerjaan. Pribadi yang memiliki self efficacy positif cenderung mempunyai motivasi yang lebih besar untuk melaksanakan tugas sesuai kriteria standar yang ditetapkan. Keyakinan akan kemampuan diri mendorong individu berbuat lebih efektif dengan memilih langkahlangkah dan cara-cara yang yang akan ditempuh dalam menyelesaikan suatu tugas atau pekerjaan. Semakin tinggi self efficacy seseorang semain kuat motivasinya untuk berprestasi.

Self efficacy tumbuh dan berkembang dari perpaduan berbagai faktor determinan. Faktor-faktor tersebut adalah tingkah laku yang ditampilkan oleh model, penciptaan suasana lingkungan yang menarik perhatian individu untuk meniru, kesiapan dan kemampuan proses kognitif yang dimiliki oleh seorang individu dan faktor pribadi. Keempat variabel ini saling bertaut dan saling mempengaruhi satu dengan lainnya dalam membentuk self efficacy dalam diri individu.

Guru mempunyai peranan besar untuk mengembangkan self efficacy siswa. Guru dapat merancang pembelajarannya dengan meramu segenap faktor dominan pengembangan self efficacy. Rancangan pembelajaran tersebut dituangkan dalam prosedur istruksional.

Social learning theory yang berfokus pada learning observation dan vicarious learning mengemukakan prosedur instruksional sebagai berikut: 1) attention, 2) retention, 3) performance, dan 4) motivation. Penerapan prosedur instruksional ini secara teliti akan mengembangkan hasil prestasi pembe-

lajaran yang menanamkan self efficacy dan mendorong motivasi berprestasi siswa untuk kegiatan-kegiatan belajar berikutnya.

\section{CATATAN AKHIR:}

1. Robert Slavin, Educational Psychology: Theory and Practice (4th Ed.), Boston: Allyn and Bacon, 1996, pp. 174-175.

2. Lihat Barbara L. Martin \& Leslie J. Briggs, The Affective and Cognitive Domain: Integration for Instruction and Research, Englewood Clifss, New Yersey: Educational Technology Publications, 1986, p. 177.

3. Lihat Stephen N. Elliot, Thomas R. Kratochwill, Joan L. Cook, \& John E. Travers, Educational Psychology: Effective Learning Effective Teaching ( $3^{\text {rd }}$ Ed.), Boston: McGraw Hill, 2000, p. 222. 
4. John D. W. Andrews, The Active Self in Psychotherapy: An Integration of Therapeutic Styles Needham Height, Massachusset: Allyn and Bacon, 1991, p. 402.

5. John D. W. Andrews, The Active Self in Psychotherapy: An Integration of Therapeutic Styles, p. 388.

6. Judith Todd \& Arthur C. Bohart, Foundations of Clinical and Counseling Psychology (2nd Ed.), New York, NY: HarperCollins College Publisher, 1994, p. 349.

7. Margaret E. Bell Gredler, Learning and Instruction: Theory into Practice, terjemahan Munandir dengan judul: Belajar dan Membelajarkan, Jakarta: Rajawali, 1991, p. 395.

8. Joseph Wolpe, The Practice of Behavior Therapy (4 ${ }^{\text {th }}$ Ed.), Elmsford, New York: Pergamon Press, 1990, p. 55.

9. Barbara L. Martin and Leslie J. Briggs, The Affective and Cognitive Domain: Integration for Instruction and Research, p. 177.

10. John D. W. Andrews, The Active Self in Psychotherapy: An Integration of Therapeutic Styles, p. 411.

11. Stephen N. Elliot, Thomas R. Kratochwill, Joan L. Cook, \& John E. Travers, Educational Psychology: Effective Learning Effective Teaching (3rd Ed.), p. 222.

12. Margaret E. Bell Gredler, Learning and Instruction: Theory into Practice, p. 370

13. W. S. Winkel, Psikologi Pengajaran, Jakarta: PT Grasindo, 1991, pp. 64-75.

14. Judith Todd \& Arthur C. Bohart, Foundations of Clinical and Counseling Psychology (2nd Ed.), pp. 198-199.

15. Albert Ellis \& Russel Grieger, RET: Handbook of Rational Emotive Therapy, Volume 2, New York, NY, 1986. pp. 31-45.

16. Usman Effendi, \& Juhaya, S. Praja, Pengantar Psikologi, Bandung: Angkasa, 1985, p. 41-42.

17. Stephen N. Elliot, Thomas R. Kratochwill, Joan L. Cook, \& John E. Travers, Educational Psychology: Effective Learning Effective Teaching (3rd Ed.), p. 223.

18. John D. W. Andrews, The Active Self in Psychotherapy: An Integration of Therapeutic Styles, p. 1991.

19. Robert Slavin, Educational Psychology: Theory and Practice (4th Ed.), p. 173.

20. M. As'ad, Psikologi Industri (ed. 4), Yogyakarta: Liberty. 1995. p. 53, Anne Anastasi \& Susana Urbina, Psychological Testing ( $7^{\text {th }} E d$.), Upper Saddle River, NJ: Prentice-Hall, 1994, p. 421.

21. John D. W. Andrews, The Active Self in Psychotherapy: An Integration of Therapeutic Styles, pp. 298, 373.

22. David W. Johnson \& Roger T. Johnson, Learning Together and Alone ( $3^{\text {rd }}$ Ed.), Boston: Allyn and Bacon, 1991, p. 38.

23. Linda L. Davidoff, Introduction to Psychology, terjemahan Mari Juniati, Psikologi Suatu Pengantar, jilid 2, Jakarta: Erlangga, p. 11.

24. John D. W. Andrews, The Active Self in Psychotherapy: An Integration of Therapeutic Styles, p. 409.

25. Margaret E. Bell Gredler, Learning and Instruction: Theory into Practice, p. 381.

26. Margaret E. Bell Gredler, Learning and Instruction: Theory into Practice, p. 384.

27. Ernest R. Hilgard Gordon H. Bower, Theories of Learning, Anenew South, New York, NY: Appleton Century Crofts, 1966, p. 19. 
28. Gordon Dryden \& Jeannette Vos, The Learning Revolution: To Change the Way the World Learns, Torrance, CA, USA: The Learning Web, 1999, p. 456.

29. Elaine B. Johnson, Contextual Teaching and Learning: What it is and why it's here to stay, terjemahan Ibnu Setiawan dengan judul: Contextual Teaching and Learning: Menjadikan Kegiatan Belajar-Mengajar Mengasyikkan dan Bermakna, Ujung Berung, Bandung: 2007, pp. 288-299.

30. Bruce Joice \& Marsha Weil, Models of Teaching ( $2^{\text {nd }}$ ed.), Englewood Cliffs, New Yersey: Prentice Hall International, 1980, pp. 446-454.

31. Paul A. Alberto \& Anne C. Troutman, Applied Bahavior Analysis for Teacher ( $3^{\text {rd }}$ Ed.), Toronto: Merril Publishing Company, 1990, $23-24$.

32. John D. W. Andrews, The Active Self in Psychotherapy: An Integration of Therapeutic Styles, p. 404.

33. Robert Slavin, Educational Psychology: Theory and Practice (4th Ed.), p. 175.

\section{DAFTAR PUSTAKA:}

Anastasi, Anne, \& Susana Urbina, Psychological Testing (7th Ed.), Upper Saddle River, NJ: Prentice-Hall, 1994.

Andrews, John D. W., The Active Self in Psychotherapy: An Integration of Therapeutic Styles Needham Height, Massachusset: Allyn and Bacon, 1991.

As'ad, M., Psikologi Industri (ed. 4), Yogyakarta: Liberty. 1995.

Bower, Ernest R. Hilgard Gordon H., Theories of Learning, Anenew South, New York, NY: Appleton Century Crofts, 1966.

Davidoff, Linda L., Introduction to Psychology, terjemahan Mari Juniati, Psikologi Suatu Pengantar, jilid 2, Jakarta: Erlangga.

Dryden, Gordon, \& Jeannette Vos, The Learning Revolution: To Change the Way the World Learns, Torrance, CA, USA: The Learning Web, 1999.

Effendi, Usman, \& Juhaya, S. Praja, Pengantar Psikologi, Bandung: Angkasa, 1985.

Elliot, Stephen N., Thomas R. Kratochwill, Joan L. Cook, \& John E. Travers, Educational Psychology: Effective Learning Effective Teaching (3rd Ed.), Boston: McGraw Hill, 2000.

Ellis, Albert, \& Russel Grieger, RET: Handbook of Rational Emotive Therapy, Volume 2, New York, NY, 1986.

Gredler, Margaret E. Bell, Learning and Instruction: Theory into Practice, terjemahan Munandir dengan judul: Belajar dan Membelajarkan, Jakarta: Rajawali, 1991.

Johnson, David W., \& Roger T. Johnson, Learning Together and Alone ( $3^{\text {rd }}$ Ed.), Boston: Allyn and Bacon, 1991.

Johnson, Elaine B., Contextual Teaching and Learning: What it is and why it's here to stay, terjemahan Ibnu Setiawan dengan judul: Contextual Teaching and Learning: Menjadikan Kegiatan Belajar-Mengajar Mengasyikkan dan Bermakna, Ujung Berung, Bandung: 2007.

Joice, Bruce, \& Marsha Weil, Models of Teaching ( $2^{\text {nd }}$ ed.), Englewood Cliffs, New Yersey: Prentice Hall International, 1980.

Martin, Barbara L. \& Leslie J. Briggs, The Affective and Cognitive Domain: Integration for Instruction and Research, Englewood Clifss, New Yersey: Educational Technology Publications, 1986. 
Slavin, Robert, Educational Psychology: Theory and Practice (4th Ed.), Boston: Allyn and Bacon, 1996.

Todd, Judith, \& Arthur C. Bohart, Foundations of Clinical and Counseling Psychology (2nd Ed.), New York, NY: HarperCollins College Publisher, 1994.

Winkel, W. S., Psikologi Pengajaran, Jakarta: PT Grasindo, 1991.

Wolpe, Joseph, The Practice of Behavior Therapy (4 ${ }^{\text {th }}$ Ed.), Elmsford, New York: Pergamon Press, 1990.

Alberto, Paul A., \& Anne C. Troutman, Applied Bahavior Analysis for Teacher (3 ${ }^{\text {rd }}$ Ed.), Toronto: Merril Publishing Company, 1990. 